\title{
SAVIŽUDIŠKAS ELGESYS SERGANT ŠIZOFRENIJA
}

\author{
Justas Akavickas \\ Vilniaus universiteto Medicinos fakultetas
}

Raktažodžiai: savižudybès, šizofrenija, elgesys, savižudiškas elgesys, prevencija.

\section{Santrauka}

Savižudiškas elgesys yra viena iš pagrindinių ir skaudžiausių šizofrenija sergančių asmenų komplikacijų. Tam itakos turi demografiniai ir psichosocialiniai veiksniai: jaunesnis pacientų amžius, lytis, pajamų stygius, problemiški santykiai su artimaisiais, piktnaudžiavimas psichoaktyviosiomis medžiagomis. Siekiant sumažinti šizofrenija sergančių asmenų savižudybès tikimybę, svarbu laiku taikyti veiksmingas prevencijos priemones. Tai sunkus ir sudėtingas darbas, reikalaujantis gydytojų ir kitų sveikatos priežiūros specialistų kompetencijos. Prevencijai taikomos medikamentinès ir nemedikamentinès priemonès: antipsichoziniai vaistai, kognityvinè terapija, šeimos palaikymas. Tyrimo tikslas - išanalizuoti pagrịstą informaciją apie savižudiško elgesio sąsajas, sergant šizofrenija: savižudybei įtakos turinčius veiksnius bei jų prevencijos galimybes.

\section{Ivadas}

Savižudybės yra viena iš skaudžiausių ir opiausių problemų visoje psichikos sveikatos grandyje. Remiantis Pasaulio sveikatos organizacijos (PSO) duomenimis, kasdien kas 40 sekundžių žmogus miršta nuo savižudybès, o kiekvienais metais pasaulyje nusižudo apie 1 milijoną žmonių [1]. Mirtys nuo savižudybių trikdo šeimų, bendruomenių ir visuomenès raidą, stipriai paveikia valstybių ekonominę situaciją. Jungtinèje Karalystejje dèl šios problemos kasmet prarandama apie 190 milijonų JAV dolerių [2].

Tyrimo tikslas - išanalizuoti pagrịstą informaciją apie savižudiško elgesio sąsajas, sergant šizofrenija: savižudybei ịtakos turinčius veiksnius bei jų prevencijos galimybes.

\section{Tyrimo medžiaga ir metodai}

Taikyta sisteminè mokslinès literatūros apžvalga ir analizè. Duomenų buvo ieškoma PubMed, UpToDate bei Cochrane duomenų bazèse. Straipsniai atrinkti, jei jų pavadinimas, santrauka ar reikšminiai žodžiai nurodè, kad tyrimas tinka- mas šiai apžvalgai. Naudoti raktažodžiai: suicide, suicide behavior, schizophrenia, prevention, suicide behavior in schizophrenia.

\section{Tyrimo rezultatai ir diskusija}

Savižudišką elgesị gali skatinti ịvairūs veiksniai - genetinis paveldimumas, buvusios savižudybès šeimoje, ịvairios psichologinès priežastys: vienatve, konfliktai, stresas, krizès, nedarbas, finansinès ekonominès problemos ir kt. Viena iš pagrindinių tokio elgesio priežasčių yra psichikos sutrikimai: afektiniai, psichoaktyviujjų medžiagų vartojimas, valgymo sutrikimai bei šizofrenija [3].

Šizofrenija - psichikos sutrikimas, keliantis didelę savižudybės riziką. Sergant šia liga, 40 proc. ankstyvųjų mirčių tenka savižudybėms ir kitoms nenatūralioms mirtims [3]. Tyrimų duomenimis, nuo 18 iki 55 proc. sergančių šia liga žmonių yra nors kartą bandę nusižudyti, o nusižudo apie 13 proc. sergančiujų. Didžiausias savižudybių skaičius nustatomas po pirmojo šizofrenijos epizodo, pagerejjimo fazès metu [4].

Yra žinomi demografiniai ir psichosocialiniai veiksniai, didinantys sergančiujų šizofrenija nusižudymo riziką. Tai jaunas amžius (jaunesni nei 45 metų), vyriška lytis, vienatvė, darbo ir nuolatinių pajamų neturèjimas, nesenai ịvykusios nelaimès ar kiti skaudūs ịvykiai, prieiga prie šaunamujjų ginklų, psichoaktyviujų medžiagų vartojimas bei aukštesnis išsilavinimo lygis [4]. Savižudybių riziką didina ir tam tikri ligos simptomai (anhedonija, kliedesiai), vyraujantys konkrečiais šizofrenijos atvejais, ir buvę bandymai nusižudyti. Tyrimų duomenimis, paranoidine šizofrenijos forma sergantys pacientai yra 8 kartus dažniau linkę pakelti prieš save ranką [5]. Riziką didina ir nepakankamas antipsichotinių vaistų vartojimas, nes tokie pacientai dažnai linkę nesilaikyti paskirto gydymo plano [4].

Vienas iš pagrindinių būdų mažinti sergančiųjų šizofrenija savižudybių skaičių - tinkama prevencija. Tai sunkus ir sudètingas darbas, reikalaujantis gydytojų ir kitų sveikatos priežiūros specialistų kompetencijos. Gydytojai privalo mokèti atpažinti didelès savižudybių rizikos asmenis, kruopščiai valdyti psichozès simptomus, paskirti tinkamą antipsichozinị 
gydymą. Mokslo įrodyta, kad medikamentinès priemonès (antipsichoziniai vaistai) yra veiksmingos gydyti šizofreniją ir mažinti savižudybių riziką. Atliktos studijos taip pat atskleidè, jog klozapino vartojimas ankstyvose ligos stadijose Ženkliai sumažina savižudybių riziką [6].

Nefarmakologinès priemonès, taikomos sumažinti suicidinio elgesio riziką, taip pat turi didelès reikšmès. Tai psichosocialinė integracija, užimtumas, socialinių ịūdžiu formavimas, stebėjimas. Gydytojas, nustatęs paciento polinki i savižudybę, privalo su juo kasdien kalbètis, empatiškai išklausyti jo mintis ir suteikti palaikymą, kuris tokiems asmenims yra reikalingas. Moksliškai pripažįstama ir kognityvinè terapija, kaip viena iš nemedikamentinès savižudybių profilaktikos priemonių. Jos teikiama nauda mažina šizofrenija sergančių asmenų socialinę izoliaciją, beviltiškumo jausmą, didina užimtumą [4].

Asmenims, sergantiems šizofrenija, labai svarbus ir šeimos aspektas. Šeimos pagalba turètų būti kiekvieno sergančiojo sudedamoji gydymo dalis, užkertant kelią savižudybès rizikai. Moksliniais tyrimais nustatyta, jog šeimos intervencija ženkliai padidina tikimybę, kad pacientas reguliariai vartos medikamentus, gerina sergančiųjų socialinius bei profesinius rezultatus, mažina ligos atkryčio tikimybę [7]. Svarbu šeimos narius mokyti elgtis su šizofrenija sergančiu pacientu, paaiškinti, jog per daug išreikštos emocijos ir neigiamas požiūris ị sergantịji gali išprovokuoti savižudišką elgesį, informuoti, jog tokių asmenų ženkliai padidejusi rizika nusižudyti, paaiškinti savižudiško elgesio apraiškas, pamokyti, kaip elgtis, pastebejjus artimo žmogaus savižudiškas mintis, planus ar ketinimus pakelti prieš save ranką [4].

\section{Išvados}

1. Pacientų, sergančių šizofrenija, savižudybių rizikos veiksnių pripažinimas ir įvertinimas yra gyvybiškai svarbus, siekiant sumažinti savižudybių skaičių ir kuo labiau sustiprinti paciento gydymą.

2. Pagrindinis sergančiųų šizofrenija savižudybių prevencijos būdas - kompleksinis ir visavertis ligos gydymas, apimantis rizikos veiksniu îvertinimą, jų koregavimą, socialinės ir psichologinés pagalbos prieinamumą bei priklausomybės nuo psichoaktyviujų medžiagų valdymas.

3. Svarbu mokyti sveikatos priežiūros specialistus atpažinti asmenis, linkusius ị savižudišką elgesį, informuoti šeimos narius apie pagalbos prieinamumo galimybes, itarus, kad jų artimas žmogus gali nusižudyti.

\section{Literatūra}

1. WHO. Preventing suicide: a global imperative. http://www.who. int/mental_health/suicide-prevention/world_report_2014/en/

2. Wyatt RJ, Henter I, Leary MC, Taylor E. An economic evaluation of schizophrenia -1991. Soc Psychiatry Psychiatr Epidemiol 1995;30(5):196-205.

3. Hor K, Taylor M. Suicide and schizophrenia: a systematic review of rates and risk factors. J Psychopharmacol 2010;24(4_supplement):81-90. https://doi.org/10.1177/1359786810385490

4. Sher L, Kahn RS. Suicide in schizophrenia: an educational overview. Medicina (Kaunas) 2019;55(7).

https://doi.org/10.3390/medicina55070361

5. Fenton WS, McGlashan TH, Victor BJ, Blyler CR. Symptoms, subtype, and suicidality in patients with schizophrenia spectrum disorders. AJP 1997;154(2):199-204.

https://doi.org/10.1176/ajp.154.2.199

6. Balhara YP, Verma R. Schizophrenia and suicide. East Asian Arch Psychiatry 2012;22(3):126-33.

7. Onwumere J, Bebbington P, Kuipers E. Family interventions in early psychosis: specificity and effectiveness. Epidemiol Psychiatr Sci 2011; 20(2):113-9.

https://doi.org/10.1017/S2045796011000187

\section{SUICIDE BEHAVIOUR IN SCHIZOPHRENIA}

\section{J. Akavickas}

Keywords: suicide, suicide behavior, schizophrenia, prevention, suicide behavior in schizophrenia.

Summary

Suicidal behavior is identified as one of the major and most painful complications in people with schizophrenia. This is influenced by demographic and psychosocial factors: younger age of patients, gender, lack of income, problematic relationships with relatives, abuse of psychoactive substances. Effective prevention measures are essential to reduce the risk of suicide in people with schizophrenia. It is hard and complex work that requires the expertise of doctors and other health professionals. There is a distinction between medical and non-medical measures: antipsychotics, cognitive therapy, family support. The aim of this study was to analyze substantiated information about the links between suicidal behavior in schizophrenia: determinants and prevention options.

Correspondence to: justasakavickas@gmail.com

Gauta 2021-04-25 